\title{
Book Review: Media Law by Jacob Rowbottom*
}

\author{
Peter Coe ${ }^{1}$ \\ Anthony Collins Solicitors LLP; Institute of Advanced Legal Studies' \\ Information Law and Policy Centre, University of London
}

\begin{abstract}
A nyone engaged with media law knows that it is a fast-developing and ever-changing Aarea of scholarship and practice. Due to this almost constant evolution, coupled with its complex nature - that not only draws on different legal disciplines, but also engages arguments relating to, amongst others, media policy, philosophy, democracy and politics it presents a challenging subject for academics, practitioners and students alike. However, media law's complexity is what makes it such a fascinating subject. Indeed, in recent years, it has given rise to a myriad of controversial issues and debate, such as the use of privacy injunctions, the conflict between media freedom and regulation, media plurality, mass leaks of government information, the harvesting of our personal data to influence how we vote, and the proliferation of fake news, filter bubbles and harmful speech online, amongst many others. Ultimately, in the past decade or so, media law has emerged from the shadows. It has developed from an esoteric and niche area of law into one that permeates every facet of our lives. A day does not seem to pass without an aspect of media law, or certainly the media's interaction with the law, rather ironically, making headlines somewhere.

For these reasons, Rowbottom's book is both welcome and timely. It is also, without doubt, a tour de force that not only significantly contributes to, but also moves forward, the media law canon. I have always been a great admirer of Rowbottom's scholarship. Without fail he manages to combine exemplary analysis with an accessible writing style. This work is no different. However, why this book is so good, and why it is set apart from other 'media law' texts is not simply down to its depth of analysis and accessibility. Rather, it comprehensively and elegantly evaluates the themes and issues running throughout the media law discipline, whereas other texts tend to approach the subject as the media's 'interaction' with discrete areas of law. Indeed, Rowbottom comments in the preface that:
\end{abstract}

The view taken in this book is that the study of media law is not simply a tour of bits of tort law, crime and regulation that impact on publishers and have little else in common. Instead, media law is developing as a discipline that has certain key themes and issues that bring increasing unity to different areas of law.

* Published by Hart (2018), 375 pp f37.78 ISBN 9781782256656

1 Peter Coe is a Barrister and Associate at Anthony Collins Solicitors LLP and a Research Associate at the Institute of Advanced Legal Studies' Information Law and Policy Centre, University of London. Prior to this he was a Senior Lecturer in Law at Aston University. 
In my view, this assessment is surely correct and is reflected in the 'themes' of the book. Rowbottom argues that 'significant changes' are taking place within our media which, rather than give rise to a demise of media power itself, represent, to a degree at least, a shift in communicative power between media institutions. Accordingly, he suggests that, while the media is just one element in a broader system of mass communication, it is, without doubt, a powerful actor that performs an important set of functions. Although he recognises that 'no one can accurately predict what will happen', the approach taken in the book assumes that the distinct role of the media will remain in the UK for the foreseeable future. Thus, he argues throughout the book that a primary aim for media law must be to address concerns about the power of the media and its accountability; an argument underpinned by his view that media freedom is justified by the media's fulfilment of democratic functions that benefit the audience and public.

As Rowbottom acknowledges, the organisation of the book is different to other media law texts. For example, it features several long chapters dealing with multiple legal issues, such as defamation law and privacy considered together as 'personal rights.' Similarly, the law of contempt of court and reporting of court proceedings are also taken together in a chapter entitled 'The media and the system of justice'. To my mind this is the correct way to approach media law. These topics do not exist in a vacuum. Both in scholarship and in practice they often overlap and can exist almost symbiotically. According to Rowbottom, he has grouped them in this way to draw to the reader's attention various common issues and themes (and differences). I think he achieves this very well. The book begins by considering the concept of media freedom. This is built on in chapters 2, 3 and 4 which deal with several areas of media liability - the protection of personal rights, the administration of justice and the role of censorship. Chapter 5 departs from issues of liability to deal with the protection of the newsgathering process. Chapter 6 looks at media regulation, ownership and plurality, and chapter 7 , the last substantive chapter, considers the issues posed by digital media. Rather helpfully, the conclusion discusses the key themes and trends across all the various areas of law.

Rowbottom has managed to strike a very difficult balance: this book is accessible to a wide range of audiences, yet it provides a depth of analysis and insight that will make it invaluable to media law scholars, practitioners and students. Indeed, it has quickly become a book that I turn to on a regular basis. It is also worthy of mention that its price (around f38) makes it excellent value for money, which adds to its appeal. Media law will continue to develop at pace. Thus, Rowbottom is ahead of the curve in producing this expertly written, fascinating and timely book. Consequently, it will no doubt act as a catalyst for further work and publications in this area, as well as being a valuable and well-cited resource. Thus, I will leave the final few words to Professor Gibbons who sums up this work far more eloquently than I can. In his view, and I wholeheartedly agree, it is:

... a lucid explanation of the most important elements of legal doctrine and democratic principle with perceptive analysis of the complexities and nuances involved in deciding a legitimate role for the media, especially in the context of a fast-changing digital environment. 